\title{
FILOSOFIA E LITERATURA: A ÉTICA COMO QUIASMA NA ESCRITURA DE LEVINAS
}

\author{
Philosophy and Literature: Ethics as Chiasma in the Writing of Levinas
}

Nilo Ribeiro Junior *

Resumo: $\mathrm{O}$ artigo visa apresentar a intriga entre Filosofia e Literatura na obra levinasiana graças ao caráter genuíno de sua ética da alteridade que possibilita pensá-la como um autêntico quiasma do espírito encarnado. Trata-se de ressaltar, em primeiro lugar, a maneira de filosofar a partir da Sensibilidade e por meio da qual a intriga entre ética e linguagem se tece em função da temporalidade da sensação de outrem. Apresentam-se, em seguida, os traços literários da filosofia do autor que fazem de sua obra uma poemática, isto é, uma escrita poético-pneumática a ponto de configurá-la como uma autêntica filosofia hermenêutica pós-ontológica.

Palavras-chave: Ética. Linguagem. Temporalidade. Sensação.

Abstract: The article aims to present the intrigue between Philosophy and Literature in the work of Levinas. Thanks to the genuine character of his ethics of otherness, his work can be considered as an authentic chiasm of the incarnate spirit. First, this study will emphasize a way of philosophizing that is rooted in Sensibility and through which the intrigue between ethics and language is woven according to the temporality of the others' sensations. Then, it presents the literary traits of the author's philosophy that turn his work into a poetic-pneumatic writing that can be configured as an authentic post-ontological hermeneutic philosophy.

keywords: Ethics. Language. Temporality. Sensation.

* Doutor em Filosofia pela UCP - Universidade Católica Portuguesa - Braga, Portugal (2014). Professor de filosofia contemporânea na FAJE - Faculdade Jesuíta de Filosofia e Teologia, Belo Horizonte, Brasil. 
A investigação em torno da interface entre Filosofia e Literatura na obra de Emmanuel Lévinas parece promissora à medida que evoca o que ousaríamos denominar de "quiasma ético" presente no grande arco de sua produção filosófica. São praticamente duas figuras que sobressaem no que se refere ao quiasma. A primeira, o associa a uma espécie de dobradiça. Essa mantém ligadas porta/janela " $\mathrm{e}$ " batente, muito embora a dobradiça permaneça quase imperceptível, uma vez que o foco da atenção se volta, quase sempre, para a abertura/fechamento da janela/porta em questão. Nessa perspectiva, é como se a Ética que subjaz à Filosofia e à Literatura se mantivesse invisível embora imprescindível a fim de que se possa assegurar a visibilidade da intrínseca relação entre ambas.

A segunda, o liga à ideia de movimento que se institui em função do cruzamento entre duas linhas, sendo que o liame permite passar do mais ao menos e do menos ao mais quando da relação entre elas. Isso, porém, acontece sem que essa passagem possa ser identificada à síntese da dialética tomada no sentido vulgar. Nesse caso, é como se a Ética permitisse vislumbrar a dinâmica vital em forma de cruz (Chi grego), que vai da Filosofia à Literatura e vice-versa. E se a priori, consideradas em função do regime de separação, ambas parecem manter sua autonomia e independência, no âmbito do contato, ou melhor, no evento dessa proximidade, elas se veem, praticamente, perpassadas ou penetradas uma pela outra. Assim, elas são fendidas reciprocamente de modo que os interstícios abertos permitem o fluxo ou o trânsito de uma à outra a ponto de perderem algo de si para ganharem aquilo que as ultrapassa ou que lhes vem de fora dos respectivos domínios. Essa ênfase, portanto, naquilo que vem de um outro lado da relação, reforça a proximidade entre quiasma e Ética. É, pois, a Ética da alteridade que as introduz nessa intriga do espírito que as faz tocar uma à outra. Ora, a relação com outrem é da ordem do paradoxo graças à separação entre o Mesmo e outrem e à aproximação entre eles a ponto de evoluir para um outro-no-Mesmo.

Portanto, a partir dessas duas figuras, tem-se em mente que a trama ou a urdidura entre Filosofia e Literatura possa inspirar uma leitura quiasmática da obra levinasiana. Nessa perspectiva, parece pertinente admitir que a filosofia do autor possa ser abordada como uma "obra literária" da mesma maneira que a literatura produzida por ele não dispense o caráter eminentemente filosófico que a constitui. ${ }^{1}$

Há que recordar ainda, que a ampliação do significado desse quiasma ganhou novo fôlego no contexto dos últimos anos graças à publicação das obras inéditas do filósofo. Esses escritos deram azo para se redobrar a atenção sobre o caráter poético e, portanto, literário da Ética do autor,

${ }^{1}$ LEVINAS, Emmanuel. Eros, littérature et philosophie. Essais romanesques et poétiques, notes philosophiques sur le thème d'éros. Paris: Bernard Grasset/Imec, 2013, p.29. 
uma vez que o material de cunho eminentemente literário reunido em três volumes ${ }^{2}$, até pouco tempo desconhecido mesmo pelos estudiosos do pensamento do autor, tornou-se recentemente de domínio público. Além disso, ressalta-se que esses textos dão acesso tanto à escritura de seus dois únicos romances: Eros ou Triste Opulence e La Dame de chez Wepler, ${ }^{3}$ como às poesias editadas em russo e traduzidas para o francês, sem falar da teoria literária condensada nessa expressiva publicação. Graças, pois, à centralidade de outrem em sua escritura, o filósofo faz orbitar sua obra em torno da primazia conferida à "literatura da sensação", ${ }^{4}$ em detrimento da narratividade "atada à percepção [do outro] mormente projetada em direção à abertura do Ser e de seu tempo". ${ }^{5}$

Do ponto de vista da linguagem da sensação ou como diz o filósofo, da "sensação como linguagem", ${ }^{6}$ deve-se acrescentar que, enquanto a sensação se associa ao instante da duração do tempo [ético] que se trava no contato com o Rosto de outrem, a linguagem se caracteriza pela expressão daquele que se oferece a si mesmo na compreensão que se tem de outrem. Por isso, a "expressão aparece indelevelmente assignada pela sensibilidade".

Nessa perspectiva, a expressão consiste em instituir a socialidade por uma relação imediata e irredutível à abertura do Ser. E, consequentemente, de uma linguagem que (ex)cede toda compreensão por uma "abertura da abertura ética" da sensação devido à originalidade do tempo inaugurado pela chegada de outrem. Isso se explica porque, em primeiro lugar, a temporalização do tempo não se mostra no Dito, ou no Discurso. Afinal de contas, afirma o filósofo, no âmbito do "Dito o tempo é certamente recuperado por um Eu ativo que lembra de cor ou reconstrói na historiografia o passado volvido, ou antecipa o futuro, pela imaginação, e pela previsão, e que na escrita, ao sincronizar os signos, se reúne em presença, isto é, representa até o tempo da responsabilidade por outrem". ${ }^{8}$

Ao contrário no Dizer pré-original anterior ao Dito, "a responsabilidade por outrem não decorre de um compromisso livre, ou seja, de um presente. Ela excede todo o presente atual ou representado". Esta an-arquia - esta

\footnotetext{
${ }^{2}$ Os escritos inéditos de Emmanuel Lévinas foram publicados com introduções explicativas, sob a responsabilidade de alguns dos filósofos mais renomados na atualidade que se dedicam aos estudos do pensamento levinasiano tais como: Rodolphe Calin, Catherine Chalier, Jean-Luc Marion, Jean-Luc Nancy e Danielle Cohen-Levinas. As obras têm como título: Carnets de Captivité suivi de Écrits sur la captivité. Oeuvres 1 (2009); Parole et Silence et autres conferénces inédites au Collège philosophique. Oeuvres 2 (2009) e Eros, Litterature et Philosophie. Essais romanesques et poétiques, notes philosophiques sur le thème d'éros. Oeuvres 3 (2013).

${ }^{3}$ LEVINAS, Emmanuel. Eros, littérature et philosophie, p. 38-59; 117-127.

${ }^{4}$ Ibid. p.28.

${ }^{5}$ LEVINAS, Emmanuel. De outro modo que ser ou para lá da essência. Lisboa: Ed. Centro de Filosofia da Universidade de Lisboa, 2011, p. 84.

${ }^{6}$ LEVINAS, Emmanuel. Eros, littérature et philosophie, p. 12.

${ }^{7}$ LEVINAS, Emmanuel. Entre nós. Ensaios sobre a alteridade. Petrópolis: Vozes, 1997, p. 29.

${ }^{8}$ LEVINAS, Emmanuel. De outro modo que ser ou para lá da essência, 2011, p. 72.
} 
recusa - de se reunir em representação, tem um modo próprio de me dizer respeito: o lapso; mas "o lapso de tempo irrecuperável na temporalização do tempo não tem somente a negatividade do memorial". ${ }^{9}$ Segundo o filósofo, "o tempo passa. E essa síntese que se faz pacientemente - chamada com profundidade de passiva - é envelhecimento do ser". ${ }^{10}$

\section{Nova semântica da ética e a temporalidade da sensação}

Em função da problemática de fundo articulada em torno do tempo, da linguagem e da ética, há que salientar que a referida intriga não possa ser concebida senão em função da pergunta pelo sentido eminentemente ético da Existência humana. Segundo Levinas, a existência se tece no drama de uma interpelação cujo thauma procede da "revelação de um Rosto".${ }^{11}$ Esta, por sua vez, provoca um verdadeiro trauma a ponto de conduzir o sujeito ao estado de uma (de)posição de si. Ora, o face-a-face e a visceral afecção advinda do paradoxo de uma "proximidade sem presença" deflagra um (im)pacto que não pode ser tematizado em função do presente concebido segundo "um piscar de olhos"12.

Antes, o contato inaugura uma diacronia que se traduz concretamente no olhar que é acariciado e no ouvido que é perfurado pela voz silenciosa de outrem. Esse olhar e essa voz fazem estremecer o corpo e ressoam na carne (ex)posta à duração do instante da eternidade do tempo inaugurado pelo advento do outro que vem de alhures. Enfim, esse instante marcado pela anacronia do tempo não escoa segundo a cronologia do tempo quantificável dos relógios nem se identifica à sincronia temporal do ser na existência e na relação; sincronia na qual tudo se refere ao Il y $a$ anônimo do ser. Ao contrário, no tempo, segundo a ética da alteridade, o corpo se torna pura inspiração como corpo de outrem.

A expressão na sua pele não é uma metáfora do em si: trata-se de uma recorrência no tempo morto ou no entre-tempo que separa a inspiração e a expiração, a diástole e a sístole do coração que bate surdamente contra a parede da sua pele [...] Recorrência que é incarnação, e onde o corpo pelo qual o dar é possível torna outro sem alienar, porque esse outro é o coração - e a bondade - do mesmo, a inspiração ou o próprio psiquismo da alma. ${ }^{13}$

Essa busca de se pensar o drama da existência em função da temporalidade de outrem exigiu redobrado esforço do filósofo em cunhar uma "nova

\footnotetext{
${ }^{9}$ Ibidem.

${ }^{10}$ Ibidem.

${ }^{11}$ LEVINAS, Emmanuel. Totalidade e Infinito. Lisboa. Edições 70, 1988, p. 53.

${ }^{12}$ ROSENZWEIG, Francis. L'étoile de la rédemption. Nanterre: Editions du Seuil, 2003, p. 123.

${ }^{13}$ LEVINAS, Emmanuel. Eros, littérature et philosophie, p. 125.
} 
semântica" para a palavra ética. Afinal, a Ética faz parte do "imaginário ocidental" uma vez plasmada nesse ambiente referido ao sujeito da ação e à vida em comum. Na sua gênese, a Ética sempre esteve vinculada a um sistema de valores, às normas para o agir, à reflexão sobre o Ethos, ou ainda, foi considerada "uma camada que recobre o Ser" e, portanto, derivada daquele. ${ }^{14}$

Em outras palavras, a palavra ética se circunscreve ao léxico do pensamento filosófico grego no sentido amplo do termo. Ela se inscreve no horizonte daquele sentido em que a sintaxe e a semântica da palavra se ata ao "modo de ser" (ontologia) do homem ocidental que a pronuncia. Não se pode negar, porém, que o sentido da palavra ética tem sofrido expressiva mutação ao longo do tempo seguindo as novas tendências culturais e históricas. Isso faz com que ela oscile segundo os diversos enfoques ou correntes filosóficas, a depender da maneira como pensam a ação humana, embora nenhuma dessas postulações se oponham ao ideário da cultura greco-romana no seio da qual foi gestada.

Em contraposição a essa visão, quando se parte do fato de que subjacente à palavra ética reverbera o apelo/voz outrem, é como se a Revelação ou a Epifania de um Rosto humano se pusesse a implodir o significado ateniense da ética cunhada pelos filósofos gregos devido à precedência do hetero-logos sobre a autonomia. Trata-se, portanto, de ressaltar a significância mais antiga da palavra ética, que provém de Jerusalém, dos profetas. Nesse outro regime da significação, "a Eleição e a responsabilidade anterior à Liberdade antecipam qualquer protagonismo atribuído a atividade do sujeito agente e, consequentemente, à sua autodeterminação na ação", seja ela pessoal ou social. ${ }^{15}$

\section{A dramaticidade ética e seu caráter linguistico}

Tendo-se, pois, em vista que o centro do pensamento levinasiano gira em torno da sensação e da linguagem, isto é, do contato no qual o sujeito se faz signo a outrem como escuta da fala/silêncio do Rosto nesse drama ético do tempo que resta, percebe-se que a questão de caráter hermenêutico-linguístico o acompanhe desde o início de seu filosofar. Pois, tanto a ética como a linguagem ligadas a dramática existencial, não se deixam circunscrever ao sistema moral e tampouco ao sistema linguístico referenciado ao discurso da tradição filosófica ocidental. ${ }^{16}$

${ }^{14}$ DERRIDA Jacques; LABARRIÈRE, Pierre-Jean. Alterités, Paris: Editions Osiris, 1986, p. 70.

${ }^{15}$ Ibid. p. 71.

${ }^{16}$ Ibid. p. 70. 
Doravante, nos escritos do autor se processa uma imediata identificação entre "ética e discurso", primeiro, em função da Palavra/mandamento de um Rosto $^{17}$ e, depois, por conta da ênfase no contato/sensação com a pele de outrem cujo Enigma não deixa sequer vestígios de sua passagem porque jamais acaba de passar e se passar. Na verdade, a questão do ineditismo do sentido que a palavra ética adquire no pensamento de Levinas depende de outra concepção [judaica] do tempo inaugurada pela "eternidade trazida pelo advento de outrem". ${ }^{18}$

Nessa esteira, o contato de inter(peles)ação determina o sentido da ação segundo à (in)spiração que advém de outrem. O rasto que o Rosto deixa por ocasião da passagem na relação move, inspira, impulsiona, traumatiza o sujeito num "dar-se em ação/redenção a fundo perdido - liturgia - como um único, corpo-para-outrem". ${ }^{19}$

Chamamos rasto a esta forma de passar inquietando o presente sem se deixar investir pela forma da consciência, sulcando com raios a claridade do ostensível. Anarquicamente, a proximidade é, assim, uma relação com uma singularidade sem a mediação de qualquer princípio, de qualquer idealidade [...] Esta fórmula exprime uma maneira de ser afectado que não se deixa investir de modo algum pela espontaneidade: o sujeito afecta-se sem que a origem da afecção se torne tema de re-presentação. ${ }^{20}$

Em função disso, é, pois, de se notar que nas primeiras obras, a ética aparecesse referida ao que o filósofo denomina de "comunicação anterior à linguagem" como Revelação. ${ }^{21}$ Mais tarde, porém, nos escritos da maturidade, a ética fora associada à intriga de Dizer/Dito, isto é, a um Dizer ético que é do regime de (ex)ceção da linguagem [ontológica] graças à "sensação do outro-no-mesmo". ${ }^{22}$ Por sua vez, essa "proximidade do outro como linguagem" provoca uma alteração tal na essência, ou se se quiser, uma radical diferenciação na alma do sujeito a ponto de a subjetividade se configurar como uma "defecção, derrota da identidade do Eu" num corpo susceptível à vulnerabilidade do Rosto. ${ }^{23}$

Assiste-se, assim, a "uma fissão no núcleo do sujeito falante" de modo a conduzi-lo a uma radical destituição da vontade diante da inspiração de outrem, ao que o filósofo denomina de Redenção. ${ }^{24} \mathrm{~A}$ passagem, portanto, da Revelação à Redenção se traduz, na linguagem e no discurso absolutamente encarnados, isto é, no "signo dado a outrem no Eis-me aqui de um corpo de carne feito dom para-outrem". ${ }^{25}$

\footnotetext{
${ }^{17}$ LEVINAS, Emmanuel. Totalidade e Infinito. Lisboa. Edições 70, 1988, p. 68.

${ }^{18}$ LEVINAS, Emmanuel. De outro modo que ser ou para lá da essência, p.73.

${ }^{19}$ Ibid. p. 89.

${ }^{20}$ Ibid. p. 116-117. Grifo nosso.

${ }^{21}$ LEVINAS, Emmanuel. Totalidade e Infinito. Lisboa. Edições 70, 1988, p. 60.

${ }^{22}$ LEVINAS, Emmanuel. De outro modo que ser ou para lá da essência. p. 74.

${ }^{23}$ Ibid. p. 36.

${ }^{24}$ Ibidem.

${ }^{25}$ Ibid. p. 69.
} 
Do ponto de vista da linguagem percebe-se que Levinas tenha introduzido uma transgressão naquilo que a Semiótica nos acostumou a diferenciar entre a "linguística da língua" e a "linguística do Discurso". ${ }^{26}$ A partir da sensação de outrem, o signo passa a ser ele mesmo da ordem da significação. Interrompe-se com isso a ideia da atemporalidade do signo-língua ou mesmo abandona-se a concepção de Discurso como aquele que inaugura o tempo do qual a linguagem/língua não dispunha por si mesma pelo simples fato de apenas circunscrever-se a um "sistema de signos". ${ }^{27}$

Entretanto, no contato/sensação de outrem, o próprio signo torna-se ele mesmo lugar-sem-lugar do discurso (utópico), a ponto de se inaugurar o tempo antes distinto do signo pela fala. Nessa perspectiva, compreende-se que signo e discurso coincidam no corpo exposto - Redenção - a outrem enquanto o signo-corpo se dá "na doação de signo de si como um corpo-dado-para-outrem como testemunho do Dizer ético do indizívellbidem. ${ }^{28}$ Não se pode discursar sobre a relação com outrem a não ser dando um único sinal que o é da ordem da expressão do corpo. E esse, já dado antes mesmo de se pronunciar como doação. É, pois, assim que se passa - sem o sentido da passagem de escoamento como no tempo linear - da Revelação que dura à Redenção na qual se antecipa, na carne exposta, o por vir como duração ética da relação. Isso se deve ao significado linguístico do "eis-me aqui no acusativo dado a outrem". ${ }^{29}$

\section{Da lingua grega à nova figura linguistica no pensamento de outrem}

Levando-se, portanto, em conta o ineditismo ético-linguístico da ordem de um autêntico "logos do pró-logo", ${ }^{30}$ isto é, de "um dizer original ou pré-original" calcado em uma situação ética da linguagem que se delineia em seu caráter (pré)reflexivo, (pré)linguístico e (pré)jurídico graças à sensação/duração de outrem, nota-se que a ética do Rosto provoque uma verdadeira torção na linguagem da filosofia grega. Há por trás dessa visão uma sabedoria judaica a respeito da linguagem. Apesar dessa constatação, o filósofo lituano se apressa em dizer que seu pensamento filosófico pode e deve ser dito em "língua grega". ${ }^{31}$

A língua grega - além do vocabulário e da gramática - é a nossa linguagem universitária. Mas um texto talmúdico [...] deve estabelecer uma diferença

\footnotetext{
${ }^{26}$ RICOEUR, Paul. Interpretação e ideologias. Rio de Janeiro: Livraria Francisco Alves Editora, 1977, p. 55.

${ }^{27}$ Ibidem.

${ }^{28}$ LEVINAS, Emmanuel. De outro modo que ser ou para lá da essência, p. 158.

${ }^{29}$ Ibid. p. 33.

${ }^{30}$ Ibid. p. 27.

${ }^{31}$ LEVINAS, Emmanuel. Transcendência e inteligibilidade. Lisboa: Edições 70, 1991, p. 34.
} 
entre a "língua" grega e a "sabedoria" grega. É preciso, sem dúvida, conhecer a "sabedoria" grega quando nos intrometemos nas coisas do Estado, como se esta sabedoria fosse política no seu fundo, mas em princípio não deve ensinar-se às crianças. É preciso ensinar-lhe a "língua" grega, uma maneira de falar que, no entanto, não é a da própria Guemara [Talmude], se bem que os doutores rabínicos têm tido dela um conhecimento direto. ${ }^{32}$

Ele visa com isso assegurar que a ética enquanto linguagem possa ser comunicável ou compreendida no ambiente filosófico ocidental mesmo que se tenha de admitir que a linguagem [ética] da responsabilidade Revelação -, declinada em torno da hipérbole da substituição e da maternagem de outrem - Redenção - promova uma verdadeira implosão na (sin) taxe da filosofia grega. A ética como linguagem prescritiva do sujeito no acusativo interrompe a "maneira de pensar" da ética greco-romana. Essa tem como ponto de partida a livre determinação do sujeito autônomo ou a consciência moral marcada por certa concepção do "tempo que passa" e não pela "eternidade da duração do instante da sensação de outrem que resta" para além do sujeito, "apesar de si, como subjectum" de uma palavra/verbo responsiva que se faz carne para outrem. ${ }^{33}$

Atente-se para o fato de que a Ética enquanto linguagem da proximidade de outrem ou da ordem de um Dizer que resta, e a ética com sua linguagem ética ou de um Dito que passa, permite interromper o discurso e as formulações dos grandes sistemas da Moral ou da Ética filosófica gestadas pelo Ocidente. E se é verdade que o filósofo não tem a pretensão de propor um novo sistema ético em substituição aos atuais, há de se reconhecer que ao cavar um novo sentido para a palavra ética no âmbito do contato com outrem e da temporalidade da sensação, tenha conseguido semear o germe de um novo esquematismo ético no seio da tradição ocidental graças ao "pensamento do infinito". ${ }^{34}$ Entretanto, há de se recordar que nessa perspectiva, não é possível conceber o esquematismo senão como uma "figura" do "para si" na qual prevalece a exterioridade de um corpo que age oferecendo-se a si mesmo ao infinito do Rosto.

Nessa ótica, a ética se mostra antagônica à visão de consciência [moral] grega. Nela, o sujeito como um "em si" colhe o sentido do agir a partir de sua interioridade e de sua liberdade (para-si). No âmbito da linguagem, o fato de se privilegiar o "em si" em detrimento do "para-outrem", faz com que se mantenha intacto o tempo da reflexividade da consciência. Nela, não há interrupção da Mesmidade que vai do sujeito à lei moral e do sujeito que volta a si pela reditio completa em função da declaração do sentido da ação moral.

\footnotetext{
${ }^{32}$ Ibidem.

${ }^{33}$ LEVINAS, Emmanuel. Transcendência e inteligibilidade. Lisboa: Edições 70, 1991, p. 35.

${ }^{34}$ DERRIDA Jacques; LABARRIÈRE, Pierre-Jean. Alterités, Paris: Editions Osiris, 1986, p. 25.
} 
Como o tempo narrado se faz, no discurso, e na escrita, tempo reversível, todo o fenômeno é dito: simultaneidade do sucessivo, no tema. Na remissão ou distensão do tempo, o Mesmo modificado, retém-se ao ponto de ser perder, inscreve-se na memória e identifica-se - é dito. Vivido, estado de consciência, o ser designado por um substantivo está dis-tendido, segundo o tempo do vivido, em vida, em Essência, em verbo; através da luz que abre a diástase da identidade - através do tempo - o Mesmo encontra o Mesmo modificado; a consciência é isso mesmo. ${ }^{35}$

Na contracorrente à consciência como substantivação do tempo, a dramática relação com um Rosto introduz um "paradoxo no pensamento do tempo" em torno do qual se delineia respectivamente nova significação e novo discurso da ação humana graças ao (inter)Dizer do outro, isto é, o Dizer do infinito no finito que se diz no âmbito mesmo da finitude da relação como "outro-no-mesmo". ${ }^{36}$

Nela, se institui o "paradoxo do tempo" do infinito. Outrem interrompe o tempo da consciência embora o tempo passe a durar graças à (in)abitação do outro no instante mesmo em que ele se instaura feito um posseiro dentro do corpo do Mesmo.

Do infinito, relativamente ao qual nenhum tempo - nenhum presente - é capaz, testemunha portanto o sujeito, onde o outro está no mesmo, porquanto o mesmo é para o outro, onde a diferença da proximidade se absorve à medida que a proximidade se torna mais próxima, e, por essa mesma absorção, acusa-se gloriosamente, e acusa-me sempre cada vez mais; onde o mesmo, no seu abrigo mesmo, se vê cada mais mais cativo em relação ao outro, cativo até à substituição como refém, expiação que coincide, em última instância, com a extra-ordinária e dia-crônica inversão do mesmo no outro, na inspiração e no psiquismo. ${ }^{37}$

A partir desse horizonte, entende-se que a maneira quase paradoxal de contrapor língua e (sin)taxe no bojo do fenômeno da linguagem, não seja despropositada nem absurda. Segundo Lévinas, é possível falar a "língua" ou a linguagem de um interlocutor desconhecido ou falar uma língua estrangeira, sem, necessariamente, ter de "pensar como a pensa seu habitante" ${ }^{38}$ Isso se deve à estreita articulação entre língua, linguagem, Discurso segundo uma outra concepção de temporalidade não fugidia inaugurada pelo paradoxo da presença do "não-presente e do in-compreensível outro por meio de seu olhar e de sua voz". ${ }^{39}$

Ora, o Discurso supõe o evento da fala e a referência ao mundo sobre o qual se fala. É, pois, a essa intrínseca relação que a Linguística do Discurso

${ }^{35}$ LEVINAS, Emmanuel. De outro modo que ser ou para lá da essência, p. 58.

${ }^{36}$ Ibid. p. 45.

${ }^{37}$ Ibid. p. 161-162. Grifo nosso.

${ }^{38}$ Ibid. p. 45.

${ }^{39}$ Ibid. p. 3.2 
nos acostumou a chamar "de sintaxe/semântica do Discurso, seja ele oral ou escrito" ${ }^{40}$ Levando-se, em conta que outrem intervenha na relação, ou melhor, que a relação se estabelece em torno da temporalidade da alteridade de outrem, o Discurso com outrem "perde a referência imediata ao mundo porque ao falar dirijo-me imediatamente a um Rosto". A referência, portanto, ao mundo, perde seu poder de dar sentido, segundo a abertura do Ser, porque "outrem interpela antes que possa pensar o sentido da resposta na responsabilidade". ${ }^{41}$

Nesse horizonte perfurado pela palavra - Revelação - de outrem, entende-se que se a língua não se vê comprometida aquando da relação com outrem, o mesmo não se pode dizer do discurso. Esse passa a depender inexoravelmente da palavra única dada ao Rosto e daquilo que outrem ensina. Disso decorre, que na relação com outrem, o discurso é por excelência um "discurso interrompido". Afinal, a palavra que emerge do contato com um Rosto é um mandamento de uma lei do amor antes que se torne um amor à lei. Ela, a lei, interdita de se buscar e encontrar a referência do discurso em algo dado pelo mundo. Afinal, a lei subjaz ao discurso porque trata-se, antes, de "amar outrem segundo o mandamento dos mandamentos para além da Lei". ${ }^{42}$

\section{A comédia humana e o tempo que resta}

Do ponto de vista filosófico, recorda Lévinas, a (sin)taxe grega é aquela cuja intencionalidade tende a sincronizar o fluxo dos conteúdos da comunicação ao Discurso a fim de harmonizá-los, contemporizá-los e sintetizá-los em torno dos interlocutores. É, portanto, contra a essa "sincronia" de caráter existencial-filosófico, ${ }^{43}$ processada pelo Ethos grego, que se opõe Lévinas. Segundo ele, a precedência da dramática ou da comédia humana de caráter ético-comunicativo (pré)originária, isto é, a imediação da temporalidade do contato (sensação) com outrem, (in)terdita e (im)possibilita de se manter fiel ao discurso [filosófico] que pretenda sincronizar aquilo que no ato da linguagem [ética] se revela como sendo (a)fásico.

Na perspectiva do tempo que resta, próprio da imediação da duração do instante do contato com outrem, se delineia uma outra (des)ordem graças à (dia)cronia introduzida pela relação sem relação, ou pela sensação, na qual se processa a diferenciação no corpo-assujeitado que se faz exposição

\footnotetext{
${ }^{40}$ RICOEUR, ob. cit. p. 45.

${ }^{41}$ LEVINAS, Emmanuel. De outro modo que ser ou para lá da essência, p. 33.

${ }^{42}$ LEVINAS, Emmanuel. Hors sujet. Paris: Fata morgana, 1987, p. 87.

${ }^{43}$ LEVINAS, Emmanuel. Autrement que savoir. Paris: Editions Osiris, 1986, p. 50.
} 
na redenção. Nesse âmbito, a "linguagem encontra-se absolutamente desligada, estrangeira da língua do ser, do presente, da essência, do mesmo, da economia, etc." ${ }^{44}$

Em suma, a partir da ética como uma ótica e/ou como relação, a filosofia que brota do drama ético como ponto zero da existência interrompe o discurso coerente da filosofia grega. Basta recordar que a filosofia ocidental que se identifica ao "amor à Sabedoria nasceu da passagem do Mito ao Logos tendo como ponto de partida a reflexividade focada no sujeito do discurso que [se] conhece a si mesmo". ${ }^{45}$ A filosofia, portanto, é presidida pelo sujeito da fala, de sorte que ele se vê investido de uma racionalidade discursiva, lógica, mostrativa e, porque não dizer, de uma racionalidade demonstrativa da Razão tomada segundo o protótipo da visão e não da audição.

\section{Da linguagem ontológica à literatura do poema ético}

Há que se frisar que, segundo a visão de Lévinas, o discurso pré-original da ética como drama humano institui-se em torno da [outra] ordem do Sensível, da sensibilidade, da exposição, e da eternidade do tempo [ético] que dura. A temporalização do tempo é indissociável da auscultação de um Rosto humano cuja voz não cessa de ecoar no silêncio de um corpo susceptível que o escuta e o (ob)edece e se torna exposto a ponto de tornar-se um "corpo-todo-ouvido" para outrem.

A temporalização do tempo, abertura pela qual a sensação se manifesta, se sente, se modifica sem alterar a identidade, se duplica - por uma espécie de diástase do pontual - se desfasa -, não é nem um atributo nem um predicado que exprima uma causalidade sentida como sensação. A modificação temporal não é nem acontecimento nem ação, nem efeito de uma causa. Ela é o verbo ser. ${ }^{46}$

Isso supõe, evidentemente, uma sintaxe (an)crônica do pensamento. Calcada na inspiração do outro, trata-se de "pensar mais do que pensa a poética" a fim de que a comédia não acabe na tragédia da redução de um Rosto a um anônimo espectro do humano, tal como sugere a literatura ontológica.

A comédia começa com o mais simples de nossos gestos. Todos eles comportam uma inevitável falta de habilidade [...] Isso significa que nossa consciência e nosso domínio da realidade pela consciência não esgotam

${ }^{44}$ DERRIDA Jacques; LABARRIÈRE, Pierre-Jean. Alterités, DERRIDA Jacques; LABARRIÈRE, Pierre-Jean. Alterités, 1986, p. 17.

45 Ibidem.

${ }^{46}$ LEVINAS, Emmanuel. De outro modo que ser ou para lá da essência, p. 55. 
nossa relação com ela, que nós estamos aí presentes com toda a espessura de nosso ser. O fato de a consciência da realidade não coincidir com nossa habitação no mundo - eis o que na filosofia de Heidegger produziu forte impressão no mundo literário. ${ }^{47}$

A literatura do "poema para além da poética" ontológica, se caracteriza pela escritura versada no Dizer ou na preocupação em dizer um Dizer do Rosto humano, isto é, uma literatura focada em um Nome Próprio, enfim, na ética como temporalidade da eternidade da (in)abitação do "outro-no-mesmo". ${ }^{48}$

A subjetividade é o Outro-no-Mesmo, segundo um modo que difere também daquele da presença dos interlocutores, o um ao outro, num diálogo onde estão em paz e em acordo um com o outro. O outro no Mesmo da subjetividade é a inquietação do Mesmo, inquietação pelo Outro. ${ }^{49}$

Em suma, essa "poética do poema ético" 50 supõe uma outra subjetividade em estado de inspiração, de alteração, pelo contato com a pele e com a palavra de outrem graças ao "Pneuma do psiquismo". Esse habita as entranhas do corpo que resta. Daí o caráter "poemático" de um poema pneumático que subjaz à poética fecundada pelo tempo [ético] de outrem.

\section{De outro modo de ser ao Outramente dito da filosofia}

Do ponto de vista histórico-cultural, urge recordar que a filosofia levinasiana não tem a pretensão de propugnar uma repetição da tradição grega como o fez Martin Heidegger. ${ }^{51} \mathrm{O}$ filósofo alemão, que exerceu forte influência sobre o pensamento de Levinas, refaz a filosofia do Ser "de outro modo de ser" a partir de seu retorno aos Pré-socráticos, aos Poetas, uma vez que o foco sobre o Elemental conduziria, segundo Heidegger, ao genuíno problema do Ser enquanto adjetivo ou como verbo e jamais como substantivo ou pronome.

A preocupação central, no contexto de sua ontologia fundamental, era a de "tirar o ser do esquecimento" ao qual o submeteu a história da Metafísica ocidental. Entretanto, Heidegger atribui à ética a condição de "mera camada que recobre o Ser" e, que, portanto, com a Metafísica, também ela obnubilaria a manifestação do Ser. Nas obras posteriores ao Ser e Tempo, diz

\footnotetext{
${ }^{47}$ LÉVINAS, Emmanuel. Entre nós. Ensaios sobre a alteridade,1997, p. 24. Grifo nosso.

${ }^{48}$ LEVINAS, Emmanuel. De outro modo que ser ou para lá da essência, p.47.

${ }^{49}$ Ibidem.

${ }^{50}$ LEVINAS, Emmanuel. Noms Propres. Paris: Fata Morgana, 1976, p. 61.

${ }^{51}$ DERRIDA, Jacques. Violence et métaphysique. In: L'écriture et la différence. Paris: Editions du Seuil, 1967, p. 131.
} 
Heidegger, que "a ética viria embotar a própria linguagem poética originária do Ser". ${ }^{52}$ Eis o motivo que o leva a dar primazia à Escuta e ao silêncio do Ser a fim de que, a partir da (ob)audiência ao Ser se pudesse, quem sabe, redesenhar o lugar de uma "outra Ética ontológica fundamental em função desse Dizer do Ser para além dos Ditos da anfibologia Ser/Ente". ${ }^{53}$

Em contrapartida, Lévinas propõe um caminho inédito a fim de tirar "o outro do esquecimento". Tratava-se, então, de descer aquém dos Poetas, da Grécia arcaica, para "encontrar nos Profetas, em Jerusalém, a inspiração genuína de seu pensamento" ${ }^{54}$ Em seguida, o autor propugna um caminho em torno de uma (ex)cendência que permita reposicionar o problema da ética em função do "Bem para além do Ser", para além da ontologia. Daí que seu pensamento se plasme levando-se em conta "esses extremos do aquém e do além do Ser graças à temporalidade como Bondade inaugurada pela alteridade infinita de outrem". ${ }^{55}$

Do ponto de vista da linguagem, reconhece Levinas, a Ética do outro provoca um regime de exceção que suplanta a Poética da ontologia. Isso, porém, ocorre sem perder o contato com o "poema" aquém da poética da poesia da ontologia. Pois, esse poema não se dissocia da dramática que "se trava na situação ética do contato com outrem". ${ }^{56}$ Nela, se delineia a impressividade da sensação pela qual o Rosto solicita um corpo para outrem em função de uma inédita "(hetero)logia do Bem". ${ }^{57}$ Isso põe em questão seja os (monó)logos da alma socrática, seja os (diá)logos que o sucederam [platônicos] sempre focados na primazia dos espíritos e das consciências referenciadas à universalidade do Logos, bem como rechaça o genérico e anônimo do Il y a do Ser e sua linguagem do "se" da Poesia do Ser da ontologia.

Talvez a explicação para essa hipérbole que conduz o pensamento levinasiano a considerar como ponto de partida da filosofia a exceção ao Logos, isto é, aquilo que o excede e que, portanto, encontra no âmbito de uma Profética anterior/posterior à Poética, se justifique em função das fontes que mobilizaram o pensamento do autor desde a sua tenra idade. Originário da Lituânia, Leste europeu, sua filosofia deixa entrever uma outra tradição do pensamento atravessada pela sensibilidade de uma antropo-lógica (do humanismo do outro homem) que privilegia "a anterioridade não formal, mas existencial-temporal do outro com relação ao Mesmo". ${ }^{58}$

\footnotetext{
${ }^{52}$ HEIDEGGER, Martin. Sobre o humanismo. Rio de Janeiro: Tempo brasileiro, 1967, p. 95.

${ }^{53}$ DERRIDA, Jacques, ob. cit. p. 213.

${ }^{54}$ Ibid. p. 227.

${ }^{55}$ Ibid. p. 224.

${ }^{56}$ LEVINAS, Emmanuel. De outro modo que ser ou para lá da essência, p. 85.

${ }^{57}$ DERRIDA, Jacques, ob. cit. p. 224.

${ }^{58}$ LEVINAS, Emmanuel. Transcendência e inteligibilidade. Lisboa: Edições 70, 1991, p. 34-35.
} 
O filósofo encontrou na literatura russa, no Talmude e no Livro, isto é, nessa escritura que ele denomina da "escritura santa" na qual e pela qual outrem passa e se passa sem deixar vestígios de sua passagem, ${ }^{59}$ aquilo que traduz ou expressa o Sensível ético, isto é, a sensação (pré)originária na qual e pela qual a (in)condição humana é dada no trauma da afecção de outrem e "não no conatus essendi e na Natureza e sua linguagem que a funda". ${ }^{60}$ Disso decorre que a literatura de outrem se opõe à tradição inaugurada pela Poesia lírica, romântica e naturalista de um poeta como Hölderlin e que, em certo sentido, está por trás de Tempo e Ser ou da anfibologia do Dizer/Dito do Ser de Heidegger ${ }^{61}$.

Por outro lado, evidentemente, não se pode ignorar que Levinas seja filho de seu tempo e, concretamente, da cultura ocidental na qual se insere desde sua vinda para Estrasburgo, na França. Embora dê primazia à tradição dos Profetas sobre os Poetas em nome da alteridade de outrem, ele não deixa de vasculhar o subsolo da própria filosofia grega bem como da Literatura ocidental à procura daquilo que se processa em torno da "intriga entre dizer/dito ético suscitado pelo encontro com outrem". ${ }^{62}$

Não é de se estranhar que, do ponto de vista estritamente filosófico, Lévinas tenha encontrado, especialmente, em Platão, na expressão do "Bem para além do Ser" e, em Descartes, na "ideia do infinito", vestígios dessa anterioridade e dessa precedência da ética sobre a ontologia. Em função desse mote se poderá afirmar com o filósofo que a "bondade, associada ao Rosto, salvará o mundo", antes mesmo que o mundo seja salvo pela Beleza. E, nesse caso, essa última se encontra associada ao pensamento ontológico como lugar da compreensão e da linguagem poética por excelência da verbalidade do Ser.

\section{O contato com a poética da sensação}

Em relação à literatura universal, constata-se que o filósofo jamais deixou de deparar-se com Nomes Próprios de todas as épocas como um Willian Shakespeare ou um Dante de Alighieri, mas, especialmente, com alguns dos poetas contemporâneos como Paul Celan, Marcel Proust, Arthur Rimbaud, Maurice Blanchot com os quais manteve vivo contato no contexto da cultura francesa. ${ }^{63}$ A leitura assídua desses autores o fez encontrar uma afinidade com sua maneira de filosofar a partir do Sensível, da sensação.

\footnotetext{
${ }^{59}$ LEVINAS, Emmanuel. De outro modo que ser ou para lá da essência, p. 33.

${ }^{60}$ Ibid. p.89.

${ }^{61}$ LEVINAS, Emmanuel. Autrement que savoir, p.60.

${ }^{62}$ LEVINAS, Emmanuel. Transcendência e inteligibilidade, p. 33.

${ }^{63}$ LEVINAS, Emmanuel. Noms Propres, 1976.
} 
Focado, portanto, "em uma (proto)impressão sem intencionalidade que somente um Rosto pode assegurar fora da consciência". ${ }^{64}$

A preferência de Levinas por esse tipo de literatura se deve ao fato de ela colocar o leitor em contato com uma linguagem que, embora sendo genuinamente poética, vem atravessada, seja pela temporalidade da fruição da vida, seja pela paixão suscitada pelo contato e pela sensação de outrem. Segundo essa visão "a imediação do Sensível não se reduz ao papel gnosiológico assumido pela sensação porque se caracteriza pela exposição à ferida e à fruição". ${ }^{65}$

Melhor dizendo, trata-se segundo Levinas, de uma "exposição à ferida na fruição, o que permite à ferida atingir a subjetividade do sujeito que se regozija em si e que se põe para $\mathrm{si}^{\prime \prime} .{ }^{66}$ Por um lado, comprazimento da subjetividade experimentada por si mesmo, que é a sua própria egoidade, a sua substancialidade. Por outro, imediata desnuclearização da felicidade imperfeita que é a pulsação da sensibilidade: não coincidência do Eu consigo, "inquietação, insônia, para lá dos reencontros do presente - dor que desconcerta o eu ou o atrai na vertigem, como um abismo, para impedir que, posto em si por si, ele assuma o outro que o fere, num movimento intencional, para que se produza, nesta vulnerabilidade, a inversão do outro que inspira o mesmo" ${ }^{67}$

Disso decorre o motivo de se exaltá-la em detrimento da literatura romântica focada na percepção que se inscreve no horizonte ou na abertura do Ser. Nela, "o fato psíquico pode ter um sentido enquanto referido a um outro fato psíquico - como qualquer outro elemento do mundo da experiência dita exterior". No âmbito dessa inscrição a "percepção compreende-se por relação à memória e à espera; e, reciprocamente, a percepção, a memória, a espera, estão unidas pela sua essência cognitiva, pela sua impassibilidade, e compreendem-se [...] em relação à serenidade do teorético" ${ }^{68}$

Ao contrário da percepção, no âmbito da sensação presidida pela afecção da "relação sem relação" ou por essa espécie de uma "proximidade tangencial" com outrem, que jamais se deixa sincronizar na interlocução, a Literatura que procede dessa visão, exerce um estranho poder de arrancar do mundo, seja o protagonista, seja outrem assim como o próprio leitor; de retirá-los da condição de meros personagens ou heróis a partir dos quais se plasmam belos relatos em nome de uma "estética ostensiva da abertura do Ser oferecida como abertura à imaginação do leitor". ${ }^{69}$

${ }^{64}$ LEVINAS, Emmanuel. De outro modo que ser ou para lá da essência, p. 54.

${ }^{65}$ Ibid. p. 83.

${ }^{66}$ Ibid. p. 84.

${ }^{67}$ Ibidem.

${ }^{68}$ Ibid. p. 88.

${ }^{69}$ RICOEUR, Paul, ob. cit. p. 59. 
Nessa esteira, salta aos olhos que a "literatura da sensação" de alguns dos referidos literatos com os quais Levinas mantém estreito contato, relativiza enormemente as narrativas, sejam elas de cunho histórico ou de forte apelo ficcional, ${ }^{70}$ para focarem-se naquilo que, em princípio pareceria da ordem da insignificância de sentido tais como o que se atribui à coadjuvância humana e aos truísmos de uma troca de olhares, de um bom-dia, de um aperto de mão ou de um ninar de uma criança etc.. É pois, a partir daí que se pode ter acesso ao sentido [ético] que, se servindo dos próprios sentidos, conduziria para um "terceiro sentido", isto é, para o sentido eminentemente prescritivo-ético da escritura.

Com isso, evidenciam-se os motivos que motivaram Levinas a enaltecer uma espécie de "estética da negatividade" advinda de um contato da ordem da (an)-arquia do Dizer sem Dito, ou como sugere Adorno, de uma "estética ascética" contra as banalidades da indústria cultural para as quais até mesmo um Rosto humano se torna um anônimo objeto de comércio relegado a sua insignificância de ser.

\section{Da percepção à sensação pela ética}

A partir dessa perspectiva da ética como uma ótica, Levinas enaltece aquela função demolidora da Literatura enquanto os próprios erros e riscos, vincos e equívocos, etc. estão incluídos na (ex)critura. Esses equívocos, portanto, dão testemunho da alteração abissal e absurda da essência ou do Ser - indeterminada Perfeição como Referência da significação -, porque acentuam os vestígios do Enigma do outro. Ora, uma vez que eles encontram-se inscritos nesse tipo de Literatura, ressalta-se a própria conotação de "uma (ex)critura humana outramente dita"71 em termos de substituição e de maternagem por parte daquele interlocutor de outrem. ${ }^{72}$ No contato com outrem, ele se torna um subjectum ou um sujeito que está sob.., isto é, que suporta outrem diante do [seu] apelo visceral de sua pele. Ela afeta os ouvidos antes que a visão, a ponto de suscitar um "ser-dado como um corpo-poema para outrem". ${ }^{73}$

Por todos esses motivos, compreende-se que a Filosofia levinasiana não se configure a reboque da Literatura nem da Escritura porque ao contemplar em sua filosofia essa "tradição do humanismo do outro homem" ${ }^{74}$ advindo especialmente dessas outras fontes que enaltecem o Rosto não é possível

\footnotetext{
${ }^{70}$ LEVINAS, Emmanuel. De outro modo que ser ou para lá da essência, p. 89.

${ }^{71}$ LEVINAS, Emmanuel, Transcendência e inteligibilidade, p. 34.

${ }^{72}$ LEVINAS, Emmanuel. De outro modo que ser ou para lá da essência, p. 93.

${ }^{73}$ LEVINAS, Emmanuel. Noms Propres, p. 65.

${ }^{74}$ LEVINAS, Emmanuel. Carnets de Captivité suivi de Écrits sur la captivité. Oeuvres 1. Paris: Bernard Grasset/Imec, 2009, p. 50.
} 
separar Ética e Discurso na exata medida em que a linguagem não se separa da Literatura e da Escritura [santa] de outrem. ${ }^{75}$

Essa íntima relação que se trama graças à sensação, permitiu ao filósofo de encontrar na Literatura aquilo que ele denominará nos escritos da maturidade de um "outramente ou diversamente dito"76 como o único modo capaz de dizer o indizível da imediação sensível do Dizer ético, embora ciente de que todo Dito possa ser Poético desde que se aceite que ele deva ser constantemente (des)dito, por conta dessa "relação sem relação" com outrem. A "proximidade tangencial" com outrem interrompe continuamente a narrativa e o relato da relação presididos pela abertura ontológica. Desse modo, mesmo a ruptura do mundo ordinário anunciado "pela ficção que, em princípio sugeriria o contato com outrem como outro modo de ser"77 deverá submeter-se à voz de outrem e ao corpo exposto como poema, a fim de se escapar do equívoco do anônimo do ser subjacente à ontologia.

Levando-se em conta a vasta escritura filosófico-literária levinasiana tratar-se-á, a seguir, de pontuar en passant a maneira como se evidencia "o caráter profético-linguístico de seu pensamento".$^{78}$ Serão ressaltadas apenas algumas das referências poéticas desde os escritos da juventude até às obras da maturidade indo de O tempo e outro (1943), passando por Totalidade e Infinito (1961) para desembocar em De outro modo que o Ser (1974). Esse movimento progressivo, porém, não exime de se ter de esclarecer que ele se apoia em uma leitura pancrônica, isto é, naquela que embora possa seguir o curso dos escritos segundo certa protologia, do início para o fim, pressupõe, no entanto, o sentido ético em seu caráter escatológico que só se revela nas obras do fim do percurso filosófico do autor. É, pois, na concreção da temporalidade de outrem ou propriamente dito na inscrição da linguagem ética da sensação na obra da maturidade: De outro modo que ser, que se poderá vislumbrar de maneira plástica a estrutura quiástico-ética subjacente a todos os escritos que vêm antes. Naquela obra, tem origem o reino da "multiplicidade dos próximos", a história do messias, apenas evocado ou pressuposto nos escritos anteriores.

\section{Filosofia poética como critica literária}

Há que se acrescentar que a opção pelo estudo dessas obras tem seu motivo de ordem filosófico-literário. Parte-se da constatação de que, na obra da juventude, especialmente, em $O$ tempo e outro, ao esboçar seu projeto

\footnotetext{
${ }^{75}$ LEVINAS, Emmanuel. L'au-delà du verset. Lectures et discurs talmudiques. Paris: Editions de Minuit, 1982, p. 9.

${ }^{76}$ LEVINAS, Emmanuel, Transcendência e inteligibilidade, p. 34.

${ }_{77}$ RICOEUR, Paul, ob. cit. p. 59.

${ }^{78}$ LEVINAS, Emmanuel. De outro modo que ser ou para lá da essência, p. 167.
} 
filosófico Levinas já tenha acenado claramente para a íntima relação que se estabelece entre Literatura e filosofia na sua própria experiência filosófica.

Ao referir-se ao paradoxo e ao drama da existência concreta da qual o existente não pode tomar distância do corpo e da vida que o nutre e que o insere nesse caldo fecundo, na qual convivem o prazer e a dor, e a partir da qual o sofrimento humano prenuncia a morte inominável e indominável diante da qual se escancara "a suprema irresponsabilidade" do sujeito frente a alteridade da morte", Levinas evoca a novidade de sua filosofia como uma espécie de "crítica literária" de corte eminentemente ético-poemático.

Por conta da indizível alteridade da morte, ou do "amor forte como a morte", a Literatura surge como um outramente dito daquilo que o filósofo nomeará mais tarde com um dizer ético.

Peço-vos a permissão de voltar ainda uma vez à Shakespeare, do qual abusei ao longo dessas conferências. Mas às vezes me parece que toda a filosofia não é senão uma meditação de Shakespeare ${ }^{79}$

Nota-se, porém, que o teor filosófico dessa forma de "crítica literária" assume um significado ético-pneumático ímpar em sua obra. Por um lado, ancora sua filosofia na arte dos "comentários" da Literatura a fim de garimpar em meio à sua secularidade a essência religiosa pautada na intriga ou na relação com a alteridade do Rosto. Por outro, considera a literatura como uma escritura santa naquilo que ela revela de uma autêntica antropologia do homem eleito e responsável em sua (in)condição humana para-o-outro. Não está, pois, preocupado em dar a conhecer "a superestrutura ou a fragilidade subjacente às culturas nem de situar o contexto aos quais se circunscrevem as literaturas ditas nacionais" ${ }^{80}$

O filósofo lituano-francês cuida, portanto, de manter vivo seu ceticismo (crítico) com relação ao Mal Elemental, anônimo do Ser como Il y a que, sub-repticiamente, tende a invadir especialmente o campo da Literatura. Daí o esforço de não desvincular as obras literárias de sua singularidade profética em torno "da outreidade de outrem e da unicidade do "me" do corpo em situação de inter(pel)ação". ${ }^{81}$ Sua preocupação se concretiza em torno daquilo que significa "manter-se vigilante em saber se a literatura fala a voz do ser e de sua poesia, ou se aquela faz ressoar a voz de outrem que vem de alhures, cuja pobreza/alteza destrona a simetria da anfibologia do Ser/ente" ${ }^{82}$

A propósito disso, vale enfatizar aquilo que na produção de sua "crítica literária", Levinas ao evocar uma vez mais a obra de Shakespeare, teima em dizer sobre "o fracasso da vontade [interioridade] em relação a alteri-

\footnotetext{
${ }^{79}$ LEVINAS, Emmanuel. Le temps et l'autre. Paris: Presses Universitaires de France. 1994, p. 60. Grifo nosso.

${ }^{80}$ LEVINAS, Emmanuel. L'au-delà du verset. Lectures et discurs talmudiques, p. 8.

${ }^{81}$ LEVINAS, Emmanuel. De outro modo que ser ou para lá da essência, p. 161.

${ }^{82}$ LEVINAS, Emmanuel. L'au-delà du verset. Lectures et discurs talmudiques, p. 10.
} 
dade de outrem" ${ }^{83}$ Diante da tragédia na qual o personagem do general Macbeth, em seu esforço [da vontade humana] em vista de escapar a Outrem ao morrer, acaba por ter de reconhecê-lo em sua alteridade". Disso decorre que o "suicídio a que se resolve para evitar a servidão não se separa da dor de perder, ao passo que essa morte deveria ter mostrado o absurdo de todo jogo". ${ }^{84}$

Macbeth anela a destruição do mundo na sua derrota e na sua morte (and wish th'estate o'th'world were now undone) ou, mais profundamente ainda, Macbeth anela que o nada da morte seja de um vazio tão total como o que teria reinado se o mundo jamais tivesse sido criado [...] A possibilidade de justificação e de perdão enquanto consciência religiosa em que a interioridade tende a coincidir com o ser abre-se em face de Outrem a quem posso falar. ${ }^{85}$

Em contraste com a figura de Macbeth, que prefere dar cabo a vida a se entregar a outrem, Levinas traz para a cena outra tragédia: a de Caim que mata seu irmão Abel. Trata-se propositadamente de ressignificar o sentido do relato em função do tempo do Terceiro, da voz do Criador, que faz reverberar a anterioridade de uma profética-ética mais antiga do que a poética do ser tal como se condensa na obra de Shakespeare e do drama do "ser ou não ser". Ora, diante do fratricídio narrado no livro das origens da humanidade - Criação - "a identificação da morte com o nada convém à morte do outro no assassínio". ${ }^{86}$

Entretanto, acrescenta Levinas, "o nada apresenta-se na morte ao mesmo tempo como uma espécie de impossibilidade porque outrem e seu rosto exprime minha impossibilidade moral de reduzi-lo ao nada [...]. O movimento de aniquilamento no assassínio conduz-nos na realidade para uma ordem da qual nada podemos dizer, nem mesmo o ser, antítese do impossível nada". ${ }^{87}$ Eis que nessa outra lógica que a da Poética-narrativa, para além do sentido ontológico, se articula o ineditismo do tempo do poema da Criação, Revelação e da Redenção a partir dos quais procede o significado [ético] último que atravessa os relatos e as respectivas camadas da temporalidade do tempo ético.

\section{O poema prescritivo da responsabilidade}

Em relação à produção intermediária, em torno da obra Totalidade e Infinito, é possível perceber, nas entrelinhas de sua escritura, os ecos tanto da voz da tradição judaica do Livro mediada pelo contato "com o filósofo judeu

\footnotetext{
${ }^{83}$ LEVINAS, Emmanuel. Totalidade e Infinito, p. 209.

${ }^{84}$ Ibidem.

${ }^{85}$ Ibid. p. 209-210.

${ }^{86}$ LEVINAS, Emmanuel. Totalidade e Infinito, p. 211.

${ }^{87}$ Ibidem.
} 
Franz Rosenzweig e suas categorias da Criação-Revelação-Redenção", 88 bem como do "som do sopro" da literatura russa, especialmente, a dos Irmãos Karamazov de Dostoievski, sobretudo quando se trata dos Ditos do dizer "do drama da responsabilidade ética diante da epifania do Rosto do outro". ${ }^{89}$

No contexto dessa obra, Levinas insiste na responsabilidade como condição de se estar sob a escuta de um Rosto como se essa situação ética pré-original fosse constituinte de uma subjetividade como perseguição e martírio. Trata-se, segundo ele, de conceber a subjetividade mobilizada por "um estado de recorrência que não é consciência de si na qual o sujeito ainda se manteria distante de si mesmo na não-indiferença, na qual se manteria ainda, de uma qualquer forma, em si e capaz de velar a sua face". Antes, graças à proximidade da voz de um Rosto, na responsabilidade de um corpo susceptível à vulnerabilidade do Rosto, o sujeito encontra-se "expulso de toda a parte e de si mesmo, dizendo um ao outro eu ou eis-me"..$^{90}$

Isso reforça a ideia de que em seu pensamento Filosofia e Literatura formam um quiasma no duplo sentido da palavra e em cujo nó encontra-se a Ética de uma poética identificada imediatamente ao "poema do outro-no-mesmo". ${ }^{91}$ Daí a possibilidade de retomar o dito de Dostoievski como figura ética, isto é, como metáfora, no sentido que Levinas concede ao termo explicitado em sua Teoria linguística condensada nos escritos inéditos. A saber, não como figura de linguagem de uma linguagem Poética, mas como o próprio evento do poema no qual o Dizer ético como comunicação anterior à linguagem, provoca uma diferenciação tal no corpo a ponto de o sujeito se fazer signo dado como Eis-me aqui a outrem, interrompendo-se assim "a lógica do discurso de dominação da filosofia". ${ }^{92}$

Nessa ótica da ética da alteridade, poder-se-ia acrescentar que o dito do Dizer ético, de que "somos todos culpados de todos perante todos, e eu mais que todos os outros, tal como o descreve Dostoievski em Os Irmãos Karamázov"93 é inseparável da metáfora de um corpo que se faz signo dado a outrem. Essa metáfora, escapa, portanto, do sistema linguístico de sua "linguística da língua e do Discurso". ${ }^{44}$ Pois, "a subjetividade do sujeito como perseguição e martírio, precisamente substituição a outrem, literalmente, desse único-corpo sem situação, sem morada, expulso de toda

\footnotetext{
${ }^{88}$ Ibid. p. 15.

${ }^{89}$ SEBBAH, François-David. L"éthique du survivant. Paris: Presses universitaire de Paris Nanterre. 2018, p. 52.

${ }^{90}$ LEVINAS, Emmanuel. De outro modo que ser ou para lá da essência, p. 161.

${ }^{91}$ LEVINAS, Emmanuel. Noms Propres, p. 39.

${ }^{92}$ DERRIDA Jacques; LABARRIÈRE, Pierre-Jean, ob. cit. p. 17.

${ }^{93}$ LEVINAS, Emmanuel. De outro modo que ser ou para lá da essência, p. 161.

${ }^{94}$ RICOEUR, Paul, ob. cit. p. 56.
} 
a parte e de si mesmo, só pode "se dizer" no eis-me aqui". ${ }^{95}$ Trata-se de um eis-me como "testemunho do Infinito, mas como testemunho que não tematiza aquilo do qual dá testemunho, e cuja verdade não é verdade de representação, não é evidência". ${ }^{96}$ Por isso a literatura dostoievskiana não é senão um "outramente dito do Dizer ético" que a Poética (ontológica) alega ser da ordem do Dizer do Ser.

Em outras palavras, o Dizer da responsabilidade na "anarquia da diacronia" 97 q LEVINAS, Emmanuel. Autrement que savoir. Paris: Editions Osiris, 1988ue se furta do "dizer coerente do Ser", poderá ser Dita de maneira poética, contanto que se leve em conta a defasagem, o hiato, o lapso de tempo, a ausência do sentido que advém, não da referência à razão, ao ser, mas do Rosto de outrem. Nesse sentido, a indicibilidade ou o silêncio ético (sem-mundo), só pode ser dito no Outramente Dito (poético), desse tipo de literatura eminentemente ética como a de Dostoiévski. Pois, ela privilegia a metáfora, como embate que ocorre na sensação/diferenciação próprio do contato com um Rosto humano, "a maneira de se dizer o sentido ético da escritura que nenhum outro discurso daria conta de traduzir". ${ }^{98}$

Nessa perspectiva, entende-se também porque, embora Lévinas se aproprie da expressão de que "somos todos responsáveis de tudo e de todos, e eu mais que os outros", que consagrou a obra dostoieviskiana de Irmãos Karamozov, possa levá-la a hipérbole ao acentuar o "de todos o eu mais que os outros" da responsabilidade..$^{99}$ Se o sentido primevo da escritura literária é ético e não poético-ontológico propriamente dito, como modo de assegurar a interrupção do Il y a (Mal Elemental) que ronda até mesmo a responsabilidade, o filósofo lituano-francês evoca a condição única e singular do eu no acusativo da responsabilidade a fim de fazê-la passar pelo crivo da Razão, da consciência. O acento, portanto, recai sobre o "eu mais que os outros" responsável até mesmo pela responsabilidade de outrem. Dessa forma, o autor dá-se conta de um outramente dito ético da responsabilidade uma vez que "seu sentido procede dessa defasagem, do silêncio, da ausência, graças à eleição anterior à liberdade" ${ }^{100}$

Nessa ótica, o discurso interrompido da ética põe em questão até mesmo a referência poética do discurso. Segundo Levinas, a poética tenderia a exaltar o anônimo da voz e da escuta do ser e não o apelo ético do Rosto e da carne de outrem. Uma vez eleito por outrem, antes mesmo da escolha que se possa fazer de ser responsável, o sujeito fora destinado a um "sim"

\footnotetext{
${ }^{95}$ LEVINAS, Emmanuel. De outro modo que ser ou para lá da essência, p. 160.

${ }^{96}$ Ibid. p. 161.

${ }^{97}$ LEVINAS, Emmanuel. Autrement que savoir. Paris: Editions Osiris, 1988. p. 50.

${ }^{98}$ LEVINAS, Emmanuel. De outro modo que ser ou para lá da essência, p. 161.

${ }^{99}$ SEBBAH, François-David, ob. cit. p.52.

${ }^{100}$ LEVINAS, Emmanuel. De outro modo que ser ou para lá da essência, p. 73.
} 
na condição de acusado pelo "bem além do ser", isto é, culpado antes mesmo de qualquer pedido de desculpa.

No seu dizer, Dito enunciado e Ser, mas também testemunho, inspiração do mesmo pelo Outro, para lá da essência, extravasamento do próprio Dito por uma retórica que não é senão uma miragem linguística, que é um excendente de sentido do qual a consciência, por si só, seria incapaz, possibilidade simultaneamente de ideologia e de delírio sagrado; ideologia a manipular pela linguística, pela sociologia e pela psicologia; delírio a reduzir pela filosofia, a reconduzir à significação, ao um-para-o-outro, a uma missão rumo a Outrem, na glória do infinito. ${ }^{101}$

Em suma, a bondade que antecede e preside a dramática relação com outrem coloca radicalmente em questão o "discurso" da imputabilidade focada na (aut)arquia do sujeito. Em contrapartida, o Dizer ético, ata-se à (des)ordem de um pensamento (an)árquico, próprio de uma (de)posição com relação a qualquer linguagem romântica proveniente de uma noção de amor fusional. "Delirante sim, porque um Dizer que interrompe toda lógica mostrativa"102 marcado pela auscultação de outrem invisível, cuja aproximação não deixa tempo/lugar sequer para a imaginação. Sendo do âmbito do infinito do outro e não da indeterminada abertura do Ser e de sua Poética, o outro toma de assalto o Mesmo e ad-vém (in)abitar seu corpo-todo-ouvido.

\section{O poema pneumático de Outramente que Ser}

E, por último, em contato com a obra De outro modo que o Ser, é possível perceber que já estejamos diante de uma obra filosófica que encarna concretamente o testemunho vivo de uma linguagem poética atravessada pela Profética do Rosto. Ela é presidida pelo compasso da respiração suscitada pelo contato com outrem. Nessa ótica, essa obra retrata a inspiração do outro e a expiração do sujeito maternal inabitado pelo sopro de outrem. Entretanto, cabe reconhecer que embora a linguagem seja poética, porquanto interrompe o Dito ou o discurso coerente da linguagem discursiva da Filosofia, o fato é que em De outro modo que o Ser, o sentido [ético] desse hiato de tempo não procede da interrupção próprio da Poética, da ficção, da ontologia.

Trata-se de uma voz que vem de aquém da poética, isto é, da voz de outrem que convoca, inspira, impele e provoca a dessubstanciação e a desubstancialização da essência e obriga o sujeito a viver na (in)condição extra-

${ }^{101}$ Ibid. p. 167.

102 LEVINAS, Emmanuel. Noms Propres, p. 136. 
-ordinária de um "fora de si"; de um corpo-para-outrem como cuidado da dolência e da vulnerabilidade do outro, que pelo fato de seu Rosto revelar sua absoluta nudez, o outro do Rosto encontra-se continuamente exposto à morte. Nisso consiste, portanto, o núcleo ético desse quiasma em torno do qual se dá a urdidura em função de uma passagem que conduz da Filosofia à Literatura e vice-versa, no contexto do pensamento levinasiano.

Ora, a partir dessa obra marcada pela hipérbole da Metáfora humana por excelência dada no messianismo ou na Redenção, é possível, inclusive, explicitar o sentido ético do quiasma. Por um lado, sendo a obra De outro modo que ser, de cunho eminentemente literário-filosófico, ela exalta a "santidade" da humanidade do homem, isto é, o fato de o "Pneuma do espírito" inspirado pelo outro conduzir o eu-corpo a se dizer em um eis-me aqui em seu nome. $\mathrm{E}$ ao mesmo tempo remete o humano à carnalidade da sensibilidade exposta ao ultraje da qual não se desprega a Filosofia, preocupada em dizer do desinteressamento da essência. ${ }^{103}$

É porque a subjetividade é sensibilidade - exposição aos outros, vulnerabilidade e responsabilidade na proximidade dos outros, um-para-o-outro, ou seja, significação -, e porque a matéria é o próprio lugar do para-o-outro, a forma pela qual a significação significa antes de se mostrar como Dito no sistema do sincronismo - no sistema linguístico -, é por isso que o sujeito é de carne e osso [...] e portanto, susceptível de dar o pão da sua boca ou dar a sua pele. ${ }^{104}$

Por outro lado, a crueza da situação ética que nos põem em contato com a (in)condicional humanidade do homem marcada pela exposição, pela substituição, pelo martírio tão enaltecidos pela filosofia, não pode deixar de remeter a um corpo poemático que somente o poema (literário) seria capaz de traduzir nessa forma de um "esquecer-se de si do poeta que poetiza o que escreve qual um poema para outrem". E assim o faz graças à animação, à (bio)potência de um corpo inabitado pelo "Espírito de outrem. O sujeito exposto sabe-se "(in)capaz por si mesmo de dar-se até ao esgotamento ou a exaustão de si para outrem". ${ }^{105}$

Evidente, a obra prima Outramente que ser só se realiza como obra literário-filosófica porque subjazem a ela Nomes Próprios ou literatos contemporâneos que permitem vislumbrar a força poética de um poema sem romantismo, sem naturalismo, marcados pelo que se poderia denominar de "um (sur)realismo ético" para enfatizar uma concreção que não se vincula à vontade. ${ }^{106}$ Isso reforça, por um lado, o caráter real do drama

\footnotetext{
${ }^{103}$ LEVINAS, Emmanuel. Autrement que savoir, p. 63.

${ }^{104}$ LEVINAS, Emmanuel. De outro modo que ser ou para lá da essência, p. 95.

${ }^{105}$ LEVINAS, Emmanuel. Noms Propres, p. 59.

${ }^{106}$ RIBEIRO JR. A deshumanidade selvagem e a erótica em Lya Luft: interpelações teológicas na poética da sensação em Levinas. In: DE MORI, Geraldo; BUARQUE, Virgínia. Escritas do crer no corpo em obras de língua portuguesa. São Paulo: Loyola, 2018, p. 179.
} 
ético que subjaz a essa obra, e por outro, afirma seu caráter (sur)real, na medida em que essa obra traduz uma (ex)ceção à transcendência da Ontologia e de seu Dizer.

Por todos esses motivos, é possível retomar aquilo que havia sido apenas evocado na introdução dessa investigação a respeito do acesso concreto à escritura eminentemente poética de Levinas oferecida pelos escritos Inéditos. Eis que se pode voltar à ideia recorrente de Outramente que ser. A saber, a de que o caráter literário-poético dessa obra da maturidade não se dissocia da Poética dos romances e das poesias do autor. Entretanto, sua preocupação primordial não é a de oferecer uma escritura esteticamente irretocável do ponto de vista linguístico e semântico, mas a de deixar vir à tona a dramática existência marcada pelo contato com outrem por meio da "imediação da sensação" e da temporalidade ética enquanto eternidade na responsabilidade.

A sensação de outrem interrompe a exposição ao horror do anonimato do Ser, porque a proximidade e a linguagem que a proximidade com o outro inauguram, são suficientes para evocar um sujeito único na unicidade de uma palavra e de um corpo dados para outrem, Nome Próprio. Nessa ótica, entende-se que tantos os erros como os cortes e as correções de um texto não se reduzam a meras questões linguístico-gramaticais ou de estilo. Na perspectiva da sensação, a escritura reporta sempre ao drama ético de uma relação com outrem que está constantemente a se excrever no corpo daquele que é substituição (suporte) de outrem. Nele, outrem deixa marcas no corpo de quem não apenas escreve mas se excreve movido por outrem, de sorte a não se importar tanto com os limites do estilo, mas em não trair a assinatura da escrita, isto é, a de testemunhar que foi marcado em seu próprio corpo a ser de outrem. A plasticidade dessa escritura ética se configura no poema do autor.

\section{De nada preciso neste mundo}

Apenas do teu rosto

Que-ressoem

Apenas da lembrança dos teus refrões

Sim, diante deste rosto apenas ascender diante de ti

Apenas de ascender uma lamparina diante de teu rosto

Não conheço nem

Nem sorriso, nem raio, nem ira

Mas não choro de saudade

Rainha, ó minha rainha

Quero te ver viver

Ah, a lamparina brilha com um fogo tão fraco 
E os refrões soam tão cansados -

Ó minha rainha, eu me sufoco !

Me sufoco ó minha rainha.

Assim, a linguagem do romance e a poesia levinasianas se aproximam muito do prosaico e dos truísmos de modo a frustrar a expectativa daquele leitor ávido em encontrar em sua escrita uma métrica rigorosa, uma bela retórica ou uma construção narrativa exemplar, tal como ocorre na produção dos grandes mestres da poética ocidental. A preocupação de sua escritura não se deixa conter nem mensurar pela estetização das formas. Afinal, o autor visa dar passagem à Figura/tempo do Rosto humano capaz de suscitar no sujeito um amor visceral pelo outro a ponto de o corpo exposto a outrem se ver destituído da preocupação pela [sua] morte ou pelo Nada do Ser.

\section{Éramos três a amá-la}

Ela era radiante como um sol

Ela era bela como a vida

E éramos três a amá-la

A amá-la como o sole a vida

O primeiro a amava e dizia que ela era uma santa

O segundo a amava e dizia que ela era uma rainha

E eu a amava e dizia que ela era bela

Mas ela o sabia sem mim

Nós éramos três a sonhar com ela

O primeiro queria sonhava em estar a seus pés a orar

O segundo em tocar e beijar acariciar sua mão

E eu queria abraçá-la e beijar seus lábios

E ela me compreendia

O primeiro morreu por ela numa batalha

O segundo de saudade definhava

E eu a abraço e beijo seus lábios

E ela me ama imensamente

[Mas talvez não fôssemos três

Talvez fôssemos dois

Mas talvez não fôssemos dois

Talvez não houvesse senão somente eu ]

Em suma, a figura de outrem aquém e além da forma de um Rosto, ocupa o centro das atenções do filósofo porque aquela figura supõe que os traços do infinito só possam ser alcançados em sua (in)visibilidade por meio do silêncio, da escuta do lamento, do grito e dos últimos suspiros de um rosto. 
Isso quase o aproxima da "estética do grotesco" se não fosse a bondade do Rosto que sempre suscita um corpo, uma carne para outrem a ponto de essa tornar-se bela quanto mais dada em sacrifício. A existência ética vivida por meio dessa estética literária, deverá ser, portanto, um anúncio (profético) daquilo que é vivido na carne a respeito de uma "culpabilidade de sobrevivente"107 diante da tragédia do premente assassínio do outro.

Por outro lado, entende-se que a literatura implícita à obra Outramente que Ser, carrega os traços dessa poética dos romances e das poesias. Trata-se de uma literatura límpida, austera, sem sedução retórica, sem rodeios sobre a (in)condição da humanidade do homem destituída de sua essência como "a hemofilia que não cessa jamais de sangrar."108

Não será o homem o ser vivo capaz do fôlego mais longo na inspiração, sem ponto de paragem, e na expiração, sem regresso? Transcender-se, sair de sua casa ao ponto de sair de si, é substituir-se ao outro: no meu porto de mim mesmo, não sentir-me bem, mas, pela minha unicidade de ser único, expiar pelo outro. ${ }^{109}$

À guisa de conclusão, poder-se-ia frisar que o estatuto poemático do pensamento levinasiano permite compaginar o caráter literário de sua filosofia ao teor filosófico de sua literatura. Graças à própria escritura do filósofo detecta-se o aspecto sui generis da Literatura que a habita. Ao repassar o arco de sua produção filosófica fora possível perceber os rastros de uma literatura universal. Entretanto, para além dessa constatação, sua obra filosófica, De outro modo que ser, cumpre o anúncio profético de uma Literatura (sur)real marcada pelas hipérboles utópicas do humano. Ela não se contenta com a estética dos discursos sincrônicos da poética ontológica na qual se enaltece os heróis em detrimento da santidade do homem inspirado. Assim, sua obra pode ser identificada a uma hermenêutica de corte pós-ontológica, sobretudo, no que tange à crítica ao idealismo linguageiro que subjaz àquela. A redenção está sempre a desatinar a visão da existência humana como abertura e como linguagem referida ao Ser e não a outrem.

\section{Referências}

DERRIDA Jacques; LABARRIÈRE, Pierre-Jean. Alterités, Paris: Editions Osiris, 1986.

DERRIDA, Jacques. Violence et métaphysique. In: L'écriture et la différence. Paris: Editions du Seuil, 1967.

HEIDEGGER, Martin. Sobre o humanismo. Rio de Janeiro: Tempo brasileiro, 1967.

107 SEBBAH, Francois-David, ob. cit. p. 51.

${ }^{108}$ LEVINAS, Emmanuel. De outro modo que ser ou para lá da essência, p. 159.

${ }^{109}$ Ibid. p. 193. 
LEVINAS, Emmanuel. Noms Propres. Paris: Fata Morgana, 1976.

. L'au-delà du verset. Lectures et discurs talmudiques. Paris: Editions de Minuit, 1982. Autrement que savoir. Paris: Editions Osiris, 1986.

_. Hors sujet. Paris: Fata morgana, 1987.

_.. Totalidade e Infinito. Lisboa. Edições 70, 1988.

. Transcendência e inteligibilidade. Lisboa: Edições 70, 1991.

. Le temps et l'autre. Paris: Presses Universitaires de France. 1994.

__. Entre nós. Ensaios sobre a alteridade. Petrópolis: Vozes, 1997.

_. Humanismo do outro homem. Petrópolis: Vozes, 2009a

_. Carnets de Captivité suivi de Écrits sur la captivité. Oeuvres 1. Paris: Bernard Grasset/Imec, 2009b.

. Parole et Silence et autres conferénces inédites au Collège philosophique. Oeuvres 2. Paris: Bernard Grasset/Imec, 2009c.

De outro modo que ser ou para lá da essência. Lisboa: Ed. Centro de Filosofia da Universidade de Lisboa, 2011

. Eros, littérature et philosophie. Essais romanesques et poétiques, notes philosophiques sur le thème d'éros. Paris: Bernard Grasset/Imec, 2013.

RIBEIRO JR. A deshumanidade selvagem e a erótica em Lya Luft: interpelações teológicas na poética da sensação em Levinas. In: DE MORI, Geraldo; BUARQUE, Virgínia. Escritas do crer no corpo em obras de língua portuguesa. São Paulo: Loyola, 2018, p.177-194.

ROSENZWEIG, Francis. L'étoile de la rédemption. Nanterre: Editions du Seuil, 2003.

RICOEUR, Paul. Interpretação e ideologias. Rio de Janeiro: Livraria Francisco Alves Editora, 1977.

SEBBAH, Francois-David. L"éthique du survivant. Paris: Presses universitaire de Paris Nanterre. 2018.

Endereço do Autor:

Av. Dr. Cristiano Guimarães, 2127

Planalto

31720-300 Belo Horizonte - MG 